\title{
DEVELOPMENT OF VERTEBRATE PEST MANAGEMENT MODELS FOR SUGARCANE CROP
}

\author{
Syeda Azra Tariq, Amjad Pervez, Syed Muzaffar Ahmed and Hina Zafar \\ Vertebrate Pest Control Institute, Southern-Zone Agricultural Research Centre, \\ Pakistan Agricultural Research Council, Karachi University Campus, Karachi-75270 \\ Email: sazratariq@yahoo.com
}

\section{ABSTRACT}

Sugarcane crop is heavily damaged by a complex of rodent species and wild boar. The damaged sugarcane becomes infested with microorganisms and other physiological stresses, resulting in reduction of weight and sugar recovery. In this regard a study was carried out to know the damage caused by rodents to four varieties of sugar cane grown at Thatta. In these studies maximum damage by rodents was observed to BL-4 (10.29 $\pm 0.44 \%)$ variety followed by BL-129 (10.23 \pm 0.35$)$ and Thatta-10 (7.31 $\pm 0.22 \%)$ in the month of November. To manage the vertebrate pests Integrated Pest Management approach was tested and the pest management model is designed for its adoption by the sugarcane growers after research and practical studies. In these studies egg mixed brodifacoum bait proved the most promising one in achieving $(92.55 \pm 0.55 \%)$ rat reduction followed by bromdiolone $(89.87 \pm 0.6 \%)$ and Zinc Phosphide bait (84.10 $\pm 1.00 \%)$. Paraffinized Zinc Phosphide Capsular Technology used to kill wild boar population proved very successful by reducing the activity upto 98.11 Percent on the fifth day. The proposed model is a combination of mechanical, chemical and habitat manipulation approaches, which will help to enhance the crop yield through minimizing pest infestation.

\section{INTRODUCTION}

\section{Sugarcane}

(Saccharum officinarum) is a major, widespread cash crop of Pakistan. It is a high value crop for making sugar, sugarrelated products, chipboard, paper etc. The crop accounts for $3.6 \%$ value added share in agriculture and $0.7 \%$ share in GDP of the country (Pakistan Economic Survey 2017-18). It provides raw material to approximately 77 sugar factories besides indigenous "brown sugar" cottage industry (A. P. Com, 2003). Sugar industry is the second largest industry after textile and plays an important role in economy of the country (Memon, 2002). It must spearhead the research and development efforts so as to meet its raw material requirements (Hussain et. al. 2006). Sugarcane is a profitable crop for growers as long as growing problems do not overtake the fields. One of the major problems is invasion of the vertebrate pests. Sugarcane crop is heavily damaged by a complex of rodent species including Bandicota bengalensis, Nesokia indica, Millardia meltada and Mus booduga and wild boar, Sus scrofa. Sugarcane is a long duration crop and thus provides an ideal condition for a complex of rodent population to subsist and cause extensive damage through eating into internodes and roots. This damage becomes more prominent in lodged sugarcane. Rat damaged sugarcane becomes infested with various microorganisms and other physical stresses resulting in reduction of its weight and sugar recovery. Hampson (1984), recorded $3.7 \%$ (range $3-4 \%$ ) mean sugar loss for every $10 \%$ 
damage of sugarcane. In a rat damage survey by Fulk et. al (1980) at Fauji Sugar Mill, Khoski, Badin, $10.7 \%$ loss to sugar production was recorded. In a rodent control program conducted in sugarcane growing areas of Army Welfare Sugar Mills, Badin district, 2\% Zinc Phosphide baiting decreased $74 \%$ rodent population (Khan and Munir, 2006).

After extensive surveys conducted in Punjab and Sindh provinces, a complex of five rodent pest species and wild boar have been recorded to invade and inflict severe damage to sugarcane crop. These rat pest species are: lesser bandicoot rat, Bandicota bengalensis; softfurred field rat, Millardia meltada; short-tailed mole rat, Nesokia indica; Indian gerbil, Tatera indica and field mouse, Mus booduga. Wild boar, Sus scrofa, causing enormous damage in Punjab and Sindh provinces and is considered a major pest of sugarcane. Rats and wild boar have been reported to collectively causing an annual loss of 457.5 million rupees approximately. In view of severity of the problem and to obtain high sugar yield, many scientists of Vertebrate Pest Control Institute conducted in-depth laboratory and field trials related to rodent and wild boar management through traditional and poison baiting (Smythe, 1977; Fulk et. al., 1978 \& 1980; Smiet et. al., 1979 \& 1980; Beg \& Khan,
1982; Shafi \& Khan, 1983; Brooks et. al., 1989; Shafi \& Khokhar, 1989; Khan, 1991; Khokhar et. al., 1995; Khokhar \& Rizvi, 1995, 1998 \& 1999; Pervez et. al., 1999 \& 2005; Roberts, 1997; Rizvi, 2004; Pervez et. al., 2016; Tariq et. al., 2016 \& 2017).

An Integrated Pest Management approach was practiced to manage rodents and wild boar damage. The package successfully developed after a series of trails and is now ready for adoption by the end-users.

\section{MATERIAL AND METHODS}

The experiments were carried out at National Sugar Crop Research Center (NSCRC) experimental farms and farmer's fields at Makli, Thatta. The IPM based rat control trails were conducted on three sugarcane varieties, i.e., Thatta-10, BL-4 and BF129 (Gulabi).

Rat management approaches were based on:

\section{Mechanical}

Snap traps

Gopher Kill traps

Live traps

\section{Chemical}

Use of Zinc Phosphide bait Use of brodifacoum bait
Use of Aluminum Phosphide tablets

\section{Habitat Modification}

Removal of weeds

Sanitation of bunds

\section{Wild boar Capsular Technique}

For wild boar control poison baiting through embedding Zinc Phosphide capsule in wheat flour dough was applied with strict vigilance to avoid any mishap of eating by non-target species.

\section{RESULTS}

Results of the studies are depicted in Tables-8. Table-1 shows overall percentage of sugarcane damaged by different rodent species on three sugarcane verities during July, September and November 2007. BL-4 variety was recorded the worst attacked by rats followed by BF-129 variety. Whereas, Thatta-10 was least damaged by rats. The damage variation among the three verities was highly significant in the month of July whereas significant in the months of September and December (Table-2). Rodent control trails were conducted at various growth stages of crop on three different varieties, viz Thatta-10, BL-4 and BF-129. The results of additive poison baiting [using mixture of wheat flour and broken rice as bait base, egg $3 \%$ and Brodifacoum rodenticides $\quad(0.005 \%)]$ proved very promising bait for successful control of rodent pest population. This bait 
package, named as PARC Rat Bait, has already been tested in sugarcane crop resulting $92.63 \%$ reduction in pest population (Table-3). As per results reduction in rodent activity was highly significant after poison baiting (Table-4). Besides, rats on bunds can be controlled through fumigation by Aluminum Phosphide tablets commonly known as Detia tablets.

For wild boar control, Zinc Phosphide capsule embedded in wheat flour dough and coated with milk powder have proved very successful in eradication of their population. The trails were carried out in sugarcane fields in four district of Punjab (Table-5). The trials were very successful and the bait intake and reduction in activity was reduced from 92.67 to 98.11 Percent on the fifth day (Table-6), complete results are shown in Tables 5 \& 6. Wild boar control trails using capsular baiting technique in sugarcane field trails proved very successful by declining pig activity. In Table -7 mean reduction in intake/activity of the bait by wild boar in all the areas of the four districts is depicted. The results were highly significant for all the areas and district in regard of reduction in wild boar activity (Table-8) accordance.

\section{DISCUSSION}

Rodents are one of the major problems directly concerning to the production, storage and processing of the agricultural crops a accordance nd their eventual utilizations by man and his livestock as food (Sarwar et al., 2011; Sarwar,2015 a; Sarwar, 2015 b). Sugarcane is highly vulnerable to attack by a complex of rodent pest species due to its long duration thus providing an excellent protective cover for rats to feed and thrive almost throughout the year (Smiet et. al., 1978 \& 1980; Khan and Munir, 2 accordance 006). The results of the treatments of three rodenticidal bait formulations clearly indicated the success of PARC Rat Bait in red accordance uction of rodent population and decline in sugarcane damage. Observations on the damage survey conducted during 2007 in Thatta District shows that BL-4 was heavily attacked variety due to its softness compared to Thatta-10 and BF -129. It is worth mentioning that BL-4 is the most grown sugarcane variety in lower Sindh (Smiet et. al. 1980). Results of the experiments of rodent control using acute Zinc Phosphide bait with egg and second generation anticoagulant baits of brodifacoum and bromadiolone rodenticides $(0.005 \%$ each $)$ mixed with egg were applied in pellet form. In these studies egg mixed brodifacoum bait proved the most promising one in achieving $(92.55 \pm 0.55 \%)$ rat reduction followed by bromdiolone $(89.87 \pm 0.6 \%) \quad$ and Zinc Phosphide bait

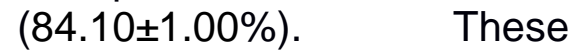
findings are in line with the trials conducted in paddy and wheat by Pervez et. al. 1999 \& 2005. Similar poison baiting trails conducted for sugarcane in India and Elsevier by Hampson (1984) have clearly shown the complete control of rodent pests and reduction in damage to crop. Performance of bait offered is affected by a number of ecological factors in field situation, such as rodent species composition, post-control re-infestation, stage of crop development, climatic factors, crop harvesting time and intercropping heterogeneity (Parshad et. al., 1986). By considering all these factors, the rodent and wild boar management package is developed for these pests.

Paraffinized Zinc Phosphide Capsular Technology was used to kill wild boar population successfully. In the Punjab, $80.4 \%$ to $100.0 \%$ reduction in pig activity was noted through application of the capsular technique (Khokhar \& Rizvi, 1998) these previous studies are in accordance with these findings. The damage studies were conducted in early maturity stage of crop when less dense cover was 
available for pigs. Wild boar is also known to cause colossal losses to wheat, maize, vegetables, cotton and fruit crops (Khokhar and Rizvi, 1998) and by using this poison capsular technology the pest may be managed.

Table-1 Damage by Rats to Different Sugarcane Varieties at District Thatta

\begin{tabular}{|c|c|c|c|}
\hline Varieties & \multicolumn{2}{|c|}{ Month wise Percent Damage (Mean \pm SE) } \\
\hline & July & September & November \\
\hline Thatta-10 & $5.85 \pm 0.15$ & $6.73 \pm 0.37$ & $7.31 \pm 0.22$ \\
\hline BL-4 & $9.34 \pm 0.28$ & $9.13 \pm 0.57$ & $10.29 \pm 0.44$ \\
\hline BF-129 & $6.08 \pm 0.09$ & $9.97 \pm 0.25$ & $10.23 \pm 0.35$ \\
\hline LSD $^{0.05}$ & 0.61182 & 1.253 & 1.1144 \\
\hline
\end{tabular}

Table-2 ANOVA for Damage by Rats to Different Sugarcane Varieties

\begin{tabular}{|c|c|c|c|c|c|c|}
\hline Months & & Sum of Squares & df & Mean Square & $\mathbf{F}$ & Sig. \\
\hline $\begin{array}{l}\text { Percent } \\
\text { damage }\end{array}$ & Between Groups & 30.47625 & 2 & 15.238125 & 104.2953 & 5.9527E-07 \\
\hline (July) & Within Groups & 1.31495 & 9 & 0.146105556 & & \\
\hline $\begin{array}{l}\text { Percent } \\
\text { damage }\end{array}$ & Between Groups & 23.31291667 & 2 & 11.65645833 & 24.01207 & 0.00024651 \\
\hline (September) & Within Groups & 4.368975 & 9 & 0.485441667 & & \\
\hline $\begin{array}{l}\text { Percent } \\
\text { damage }\end{array}$ & Between Groups & 21.11291666 & 2 & 9.655833113 & 22.01207 & 0.00234521 \\
\hline (November) & Within Groups & 4.368975 & 9 & 0.485441667 & & \\
\hline
\end{tabular}

Table-3 Reduction in Rodent Population in Sugarcane Crop after Three Different Bait Formulations

\begin{tabular}{|c|c|c|c|}
\hline Treatment & $\begin{array}{l}\text { Pre-Treatment } \\
\text { Activity }\end{array}$ & $\begin{array}{l}\text { Post-Treatment } \\
\text { Activity }\end{array}$ & $\begin{array}{l}\text { Reduction in } \\
\text { Rodent Activity (\%) }\end{array}$ \\
\hline $\begin{array}{l}\text { Brodifacoum* } \\
(0.005 \%) \\
\text { with egg additive }\end{array}$ & $\begin{array}{l}94.25 \pm 1.55 \\
e\end{array}$ & $7.00 \pm 0.41$ & $92.55 \pm 0.55$ \\
\hline $\begin{array}{l}\text { Bromadiolone } \\
(0.005 \%) \\
\text { with egg additive }\end{array}$ & $83.75 \pm 2.75$ & $8.50 \pm 0.65$ & $89.87 \pm 0.6$ \\
\hline $\begin{array}{l}\text { Zinc Phosphide } \\
(2.00 \%) \\
\text { with egg additive }\end{array}$ & $\begin{array}{r}79 \pm 3.58 \\
\end{array}$ & $12.5 \pm 0.65$ & $84.10 \pm 1.00$ \\
\hline
\end{tabular}


DOI: 10.35380/sugar.034.04.0151

Table-4 ANOVA for Reduction in Rodent Population in Sugarcane Crop after Three Different Bait Formulations

\begin{tabular}{|l|l|l|l|l|l|l|}
\hline Bait Formulations & & $\begin{array}{l}\text { Sum of } \\
\text { Squares }\end{array}$ & df & Mean Square & F & Sig. \\
\hline Pretreatment activity & Between Groups & 487.1666 & 2 & 243.5833 & 8.0155 & 0.0100 \\
\hline & Within Groups & 273.5 & 9 & 30.3888 & & \\
& Total & 760.6666 & 11 & & & \\
\hline $\begin{array}{l}\text { Post treatment } \\
\text { activity }\end{array}$ & Between Groups & 64.6666 & 2 & 32.3333 & 24.25 & 0.0002 \\
\hline & Within Groups & 12 & 9 & 1.3333 & & \\
\hline & Total & 76.6666 & 11 & & & \\
\hline Reduction in activity & Between Groups & 149.2446 & 2 & 74.6223 & 32.9311 & 7.2428 \\
\hline & Within Groups & 20.394075 & 9 & 2.266008333 & & \\
\hline & Total & 169.6386917 & 11 & & & \\
\hline
\end{tabular}

Table-5 Bait Intake of Wild Boar in Sugarcane Fields of the Punjab

\begin{tabular}{|l|l|l|l|l|l|}
\hline Area & Day-1 & Day-2 & Day-3* & Day-4* & Day-5 $^{*}$ \\
\hline Sheikhupura District & & & & & \\
\hline Langowal & $55 / 10$ & $76 / 42$ & $100 / 46$ & $46 / 31$ & $45 / 1$ \\
\hline Gatiawala & $105 / 95$ & $131 / 130$ & $151 / 145$ & $145 / 101$ & $145 / 5$ \\
\hline Sultanpura & $97 / 75$ & $110 / 70$ & $123 / 101$ & $101 / 59$ & $101 / 8$ \\
\hline Sialkot District & & & & & \\
\hline Dally Wali & $125 / 100$ & $408 / 265$ & $391 / 300$ & $300 / 263$ & $300 / 19$ \\
\hline Ghazipur & $85 / 80$ & $205 / 190$ & $346 / 240$ & $240 / 201$ & $240 / 7$ \\
\hline Gurukhair & $101 / 100$ & $400 / 300$ & $450 / 345$ & $345 / 250$ & $345 / 19$ \\
\hline Faisalabad District & & & & & \\
\hline RB-121 & $51 / 25$ & $53 / 28$ & $58 / 31$ & $31 / 11$ & $31 / 2$ \\
\hline Sahuwala & $149 / 180$ & $200 / 83$ & $206 / 94$ & $206 / 131$ & $206 / 7$ \\
\hline Motaili & $139 / 120$ & $201 / 143$ & $249 / 181$ & $181 / 93$ & $181 / 0$ \\
\hline Gujrat District & & & & & \\
\hline Hill Minhasa & $50 / 50$ & $190 / 120$ & $153 / 105$ & $133 / 91$ & $138 / 3$ \\
\hline Tool Chapala & $195 / 152$ & $209 / 140$ & $208 / 150$ & $150 / 115$ & $150 / 11$ \\
\hline Simbly Rai & $153 / 105$ & $169 / 151$ & $191 / 159$ & $159 / 75$ & $159 / 3$ \\
\hline
\end{tabular}

${ }^{*}$ Number of dough balls placed/Number of dough balls eaten. 
Table-6 Reduction in bait intake/ Activity up to five days

\begin{tabular}{|c|c|c|c|c|c|c|c|c|c|c|c|c|}
\hline \multirow[t]{3}{*}{ Days } & \multicolumn{12}{|c|}{ Reduction in bait intake/ activity (\%) } \\
\hline & \multicolumn{3}{|c|}{ Sheikhupura District } & \multicolumn{3}{|c|}{ Sialkot District } & \multicolumn{3}{|c|}{ Faisalabad District } & \multicolumn{3}{|c|}{ Gujrat District } \\
\hline & Langowal & Gatiawala & Sultanpura & $\begin{array}{l}\text { Dally } \\
\text { Wali }\end{array}$ & Ghazipur & Gurukhair & $\mid \begin{array}{l}\text { RB- } \\
121\end{array}$ & Sahuwala & Motaili & \begin{tabular}{c|c} 
Hill \\
Minhasa
\end{tabular} & $\begin{array}{c}\text { Tool } \\
\text { Chapala }\end{array}$ & $\begin{array}{c}\text { Simbly } \\
\text { Rai }\end{array}$ \\
\hline 1 & 81.81 & 9.52 & 22.68 & 5.8820 & 5.88 & 0.99 & 50.98 & \begin{tabular}{l|l}
17.22 \\
3
\end{tabular} & 13.67 & 0 & 22.05 & 31.37 \\
\hline 2 & .74 & 0.76 & 36.36 & .05 & 7.32 & 25 & 47.16 & 58.5 & 28.86 & 36.84 & 33.01 & 10.65 \\
\hline 3 & חم & 70 & 89 & 3.27 & 3001 & 23.33 & 46.5 & 54.37 & 27.31 & 31.37 & 27.88 & 16.75 \\
\hline 4 & 32.61 & 30.34 & 41.58 & 12.33 & 16.25 & 27.54 & 64.52 & 36.41 & 48.62 & 31.58 & 23.33 & 52.83 \\
\hline 5 & 97.78 & 96.55 & 92.08 & 93.67 & 97.08 & 94.49 & 93.55 & 96.6 & 100 & 97.83 & 92.67 & 98.11 \\
\hline
\end{tabular}

Table-7 Mean bait intake by wild boar up to five days

\begin{tabular}{|l|ll|l|l|}
\hline District & Area & Mean of five days intake & Std.Deviation & Std. Error \\
\hline Sheikhupura & Langowal & 62.19 & 26.91 & 13.46 \\
& Gatiawala & 28.23 & 39.89 & 19.95 \\
& Sultanpura & 42.12 & 29.56 & 16.73 \\
\hline Sialkot & Dally Wali & 36.87 & 32.79 & 16.40 \\
\hline \multirow{5}{*}{ Faisalabad } & Ghazipur & 31.47 & 37.10 & 18.10 \\
\hline \multirow{5}{*}{ Gujrat } & Gurukhair & 34.27 & 35.31 & 17.65 \\
\hline & SB-121 & 60.55 & 19.82 & 9.91 \\
\hline & Motaili & 43.69 & 29.53 & 14.76 \\
& Hill Minhasa & 39.524 & 33.85 & 16.93 \\
\hline & Tool Chapala & 39.788 & 35.70 & 17.85 \\
\hline & Simbly Rai & 41.942 & 29.87 & 14.94 \\
\hline
\end{tabular}

Table-8 ANOVA for reduction in activity by wild boar in four districts

\begin{tabular}{|l|l|l|l|l|l|}
\hline Source & $\begin{array}{l}\text { Sum } \\
\text { Squares }\end{array}$ & of $\mathbf{d f}$ & Mean Square & F & Sig. \\
\hline Areas & 2572.588 & 3 & 857.5294 & 0.805031 & 0.497268 \\
\hline Districts & 1535.748 & 2 & 767.874 & 0.720865 & 0.491521 \\
\hline Area * District & 2181.016 & 6 & 363.5027 & 0.341249 & 0.91151 \\
\hline
\end{tabular}




\section{RECOMMENDATIONS}

- PARC Rat Bait has proved very successful in control of a complex of rodent pest population in sugarcane crop and recommended to sugarcane growers for safe, economical and easy rodent control.

- Zinc Phosphide Capsular Technique is recommended for wild boar control. It was found very effective when applied through flour dough balls coated with milk powder.

- Farmers' participation through arranging framer's field days, on field demonstrations and multidisciplinary approaches are recommended to knock down rats and wild boar pest population, thus to enhance the crop yield.

- To achieve long term benefits of rodent and wild boar pest problems, participation of all stake holders of the area is essential including growers, mill management and $R$ \& $D$ personnel.

\section{REFERENCES}

Agriculture Price Commission (2003). Support Price Policy. Report on sugarcane. Agriculture Prices Commission, Islamabad.

Beg, J. E. and Khan, A. A. (1982). The wild boar in Pakistan: Distribution, habitat and movement patterns. J. Agric. Sci. Pak. 4 (1-2): 46-51.

Brooks, J. E., Ahmad, E., Hussain, I. and Khan, M. H. (1989). The agricultural importance of the wild boar (Sus scrofa) in Pakistan. Trop. Pest Managnt. 35 (3): 128-131.

Pakistan Economic Survey 2017-18, Economic Advisor's Wing, Finance Division. Ministry of Finance. Islamabad.

Fulk, G. W., Smiet, A. C. and Khokhar, A. R. (1978). Movement of Bandicota bengalensis and Tatera indica as revealed by radio telemetry. J. Bomb. Hist. Soc. 76: 457-462.

Fulk, G. W., Salam, S. A. and Akhtar, M. T. (1980). Rat damage to sugarcane in Pakistan. Pakistan J. Agri. Res. 1 (2): 131-134.

Hampson, S. J. (1984). A review of rodent damage to sugarcane with criteria for the use of rodenticides. 1-18, In Proc. Conf. Org and Prac. Vert. Pest Control, Hampshire, UK.

Hussain, M.F. Anwar, S. and Hussain, Z. (2006). Economics of sugarcane in Pakistan: A price risk analysis. Int. Res. J. of Finance and Economics, Issue 4,:71-77.

Khan, M. H. (1991). Chemical control of wild boar. Training Manual, Vertebrate Pest Management. GOP/USID/DWRC/PARC, Islamabad. pp 161-163.

Khan, A. A. and Munir, S. (2006). Effect of zinc phosphide and coumatetralyl baits on rodent abundance in sugarcane field. Proc. of $41^{\text {st }}$ annual convention. Pak. Soc. of Sugar Technol.: 206-213.

Khokhar, A. R..1995. Extension-oriented control trails against wild pig. Damaging agricultural crops in Punjab. Technical report No. 1. PEP/VPCL/TARI/PARC. pp. 14.

Khokhar, A. R., Shafi, M. M and Rizvi, S. W. A. (1995). Population characteristics of wild boar (Sus scrofa cristatus) in the forested and cultivated sugarcane areas of Punjab, Pakistan. Tr. J. of Zoology 19: 81-185.

Khokar, A. R. and Rizvi, S. W. A. (1998). Productivity enhancement of rice yield through prevention of losses due to wild boar in Pakistan. Tr. J. of Zoology (22): 167-174.

Khohar, A. R. and Rizivi, S. W. A. (1999). Vertebrate pest problems in Sindh and their impact on agricultural economy. Pakistan Food and Agriculture Review. pp 7-8.

Memon, M. A. (2002). Sugar Industry in Pakistan. Pak. and Gulf Economist: 1-5. 
Parshad, V. R., Ahmed, N. and Chopra, G. (1986). Effect of ecological factors on the performance of rodenticides in sugarcane. Proc. Anim. Sci. 95(6): 726-737.

Pervez, A., Ahmed, S. M., Ahmed, S. and Rizvi, S. W. A. (1999). The significance of additive to enhance poison bait acceptance against rodents damaging paddy in lower Sindh, Pakistan. Pak. J. Zool. 37(3): 207-210.

Pervez, A., Ahmed, S. M., Ahmed, S. and Rizvi, S. W. A. (2005). Comparative field efficiency of some additive formulated baits against rodent pests of wheat crop in Sindh, Pakistan. Pak. J. Zool. 37(4): 269-274.

Pervez, A., Ahmed, S. M., \& Tariq, S. A. (2016). Assessment of sugarcane varietal damage from field rats and their management strategy in Sindh, Proceedings of 49th Annual Convention of Pakistan Society of Sugar Technologists, Pp: 235-240.

Roberts, T. J. (1997). The Mammals of Pakistan. Oxford Uni. Press. pp. 361.

Roberts, T.J. 1981. Handbook of vertebrate pest control in Pakistan. Compiled by vertebrate pest control, Karachi. p.216.

Rizvi, S. W. A. (2004). Extension oriented wild boar control trails in Talkua, Tando Allahyar, district Hyderabad, Sindh. J. Nat. Hist. Wild 3 (1): 23-27.

Smythe, W. R. (1977). Sugarcane rats of Pakistan and their control. Int. Proc: 14th Pak. Soc. Cong. Karachi: 102-107.

Smiet, A. A., Fulk, G. W. and Lathiya, S. B. (1979). Wildboar ecology in Thatta District: A preliminary study. Pak. J. Zool. 11(2): 295-302.

Smiet, A. C., Fulk, G. W. and Lathiya, S. B. (1980). Rodent ecology in sugarcane in lower Sindh, Pakistan. Acta Theiol. 25(8): 81-97.

Shafi, M. M. and Khan, A. A. (1983). Rats damage to sugarcane crop and its control. Progressive Farming 3(1): 18-22.

Shafi, M. M. and Khokhar, A. R. (1989). Some observations on wild boar (Sus scrofa) and its control in sugarcane area of Punjab, Pakistan. J. Bombay Nat. Hist. Soc. 83(1): 63-67.

Sarwar, M. 2015 a. Species Diversity, Seasonal Variation and Abundance of Rodents (Mammalia: Rodentia) Along With Their Burrow Distribution Pattern in Wheat Farmland. Journal of Basic and Applied Research International, 5 (1): 48-55.

Sarwar, M. 2015 b. Pattern of Damage by Rodent (Rodentia: Muridae) Pests in Wheat in Conjunction with Their Comparative Densities throughout Growth Phase of Crop. International Journal of Scientific Research in Environmental Sciences, 3 (4): 159-166.

Sarwar, M. 2015: Species Complex, Damage Pattern and Efficiency of Rodenticides in Controlling Rodents Attacking Rice (Oryza sativa L.) Fields, International Journal of Animal Biology, 1 (5): 202-208.

Tariq, S. A., Ahmed, S. M., Pervez, A. \& Keerio, Q. A. (2016). Laboratory Studies on Preference of Short-Tailed Mole Rat, Nesokia indica, for some Commercial Varieties of Sugarcane, Proceedings of 49th Annual Convention of Pakistan Society of Sugar Technologists, Pp: 203210.

Tariq, S. A., Ahmed, S. M., Pervez \& Zafar, H. (2017). Population dynamics of rodent pests in sugarcane, (Saccharum officinarum) in lower Sindh, Int. J. Biol. Biotech., 14 (2), Pp: 283-288. 